\title{
Transition From Sagebrush Steppe to Annual Grass (Bromus tectorum): Influence on Belowground Carbon and Nitrogen
}

\author{
Benjamin M. Rau, ${ }^{1}$ Dale W. Johnson, ${ }^{2}$ Robert R. Blank, ${ }^{3}$ Annmarrie Lucchesi, ${ }^{4}$ \\ Todd G. Caldwell, ${ }^{5}$ and Eugene W. Schupp ${ }^{6}$
}

Authors are ${ }^{1}$ Soil Scientist, USDA Forest Service, Wallowa Whitman National Forest, La Grande, OR 97850, USA; ${ }^{2}$ Professor and ${ }^{4}$ Research Associate, University of Nevada, Reno, Department of Natural Resources and Environmental Science, Reno, NV 89512, USA; ${ }^{3}$ Research Soil Scientist, USDA Agricultural Research Service, Reno, NV 89512, USA; ${ }^{5}$ Assistant Research Soil Scientist, Desert Research Institute, Reno, NV 89512, USA; and

${ }^{6}$ Associate Professor, Department of Wildland Resources and The Ecology Center, Utah State University, Logan, UT 84322, USA.

\begin{abstract}
Vegetation changes associated with climate shifts and anthropogenic disturbance have major impacts on biogeochemical cycling. Much of the interior western United States currently is dominated by sagebrush (Artemisia tridentata Nutt.) ecosystems. At low to intermediate elevations, sagebrush ecosystems increasingly are influenced by cheatgrass (Bromus tectorum L.) invasion. Little currently is known about the distribution of belowground organic carbon $(\mathrm{OC})$ on these changing landscapes, how annual grass invasion affects OC pools, or the role that nitrogen $(\mathrm{N})$ plays in carbon $(\mathrm{C})$ retention. As part of a Joint Fire Sciences-funded project called the Sagebrush Treatment Evaluation Project (SageSTEP), we quantified the depth distribution of soil $\mathrm{OC}$ and $\mathrm{N}$ at seven sites experiencing cheatgrass invasion. We sampled plots that retained sagebrush, but represented a continuum of cheatgrass invasion into the understory. Eighty-four soil cores were taken using a mechanically driven diamondtipped core drill to a depth of $90 \mathrm{~cm}$, or until bedrock or a restrictive layer was encountered. Samples were taken in $15-\mathrm{cm}$ increments, and soil, rocks, and roots were analyzed for OC and total N. We determined that cheatgrass influences the vertical distribution of OC and $\mathrm{N}$ within the soil profile and might result in decreased soil OC content below $60 \mathrm{~cm}$. We also found that OC and total $\mathrm{N}$ associated with coarse fragments accounted for at least $10 \%$ of belowground pools. This emphasizes the need for researchers to quantify nutrients in deep soil horizons and coarse fragments.
\end{abstract}

\section{Resumen}

Los cambios en la vegetación asociados con cambios en el clima y disturbios antropogénicos tienen efectos superlativos sobre los ciclos biogeoquimicos. Gran parte del interior del oeste de los Estados Unidos está dominado por ecosistemas de Artemisia tridentata Nutt. En sitios de altitud baja e intermedia dichos ecosistemas están siendo influenciados de modo creciente por la invasión de Bromus tectorum L. Se sabe poco hoy en día sobre la distribución de carbono orgánico (CO) en el suelo en estos paisajes en estado de transición, sobre cómo la invasión de este pasto anual afecta los reservorios de CO, o el rol que juega el nitrógeno (N) en la retención de carbono (C). En el marco del Proyecto de Tratamiento y Evaluación de Artemisia (SageSTEP) financiado por el programa del Joint Fire Sciences, se cuantificó la profundidad y distribución de CO en el suelo en siete sitios que están siendo invadidos por B. tectorum. Se muestrearon parcelas que retuvieron Artemisia pero que representan un continuo de situaciones de invasión de B. tectorum del estrato herbáceo. Se tomaron 84 muestras de suelo hasta una profundidad de $90 \mathrm{~cm}$ o hasta encontrar la roca madre o alguna capa restrictiva utilizando un taladro barrenador con punta de diamante. Las muestras se tomaron en incrementos de $15 \mathrm{~cm}$ y se determinó el $\mathrm{CO}$ y $\mathrm{N}$ total del suelo, las rocas, y las raíces. Se determinó que $B$. tectorum afecta la distribución vertical de $\mathrm{CO}$ y $\mathrm{N}$ dentro del perfil edáfico pudiendo resultar en una disminución del CO del suelo a profundidades mayores a los $60 \mathrm{~cm}$. También se encontró que el $\mathrm{CO}$ y el $\mathrm{N}$ total asociados a fragmentos de mayor tamaño constituyeron por lo menos un $10 \%$ de los reservorios totales del suelo. Estos resultados enfatizan la necesidad de que los investigadores cuantifiquen nutrientes en horizontes profundos y fragmentos de mayor tamaño.

Key Words: biogeochemical cycles, carbon sequestration, cheatgrass, climate change, invasive annual grass, sagebrush, soil organic carbon, total nitrogen

$\overline{\text { Research was funded by the Joint Fire Sciences Program. This paper is Contribution Number } 51}$ of the Sagebrush Steppe Treatment Evaluation Project (SageSTEP)

At the time of the research, Rau was a postdoctoral researcher, Dept Natural Resources and Environmental Science, University of Nevada, Reno, Nevada, USA.

Correspondence: Benjamin M. Rau, USDA Forest Service, Wallowa Whitman National Forest, 3502 Highway 30, LaGrande, OR 97850, USA. Email: brau02@fs.fed.us

Manuscript received 16 April 2010; manuscript accepted 7 November 2010.

\section{INTRODUCTION}

The sagebrush (Artemisia tridentata Nutt.) steppe is the most expansive shrubland ecotype in the United States, and is considered to be one of the most threatened ecosystems in North America (Noss et al. 1995). In the interior western United States, dramatic shifts in vegetation are occurring due to long-term climate change, livestock grazing, rapid population growth, fire suppression, and introduction of exotic annual grasses (Miller and Tausch 2001). Sagebrush steppe ecosystems face declining herbaceous perennial understory components, 
A.

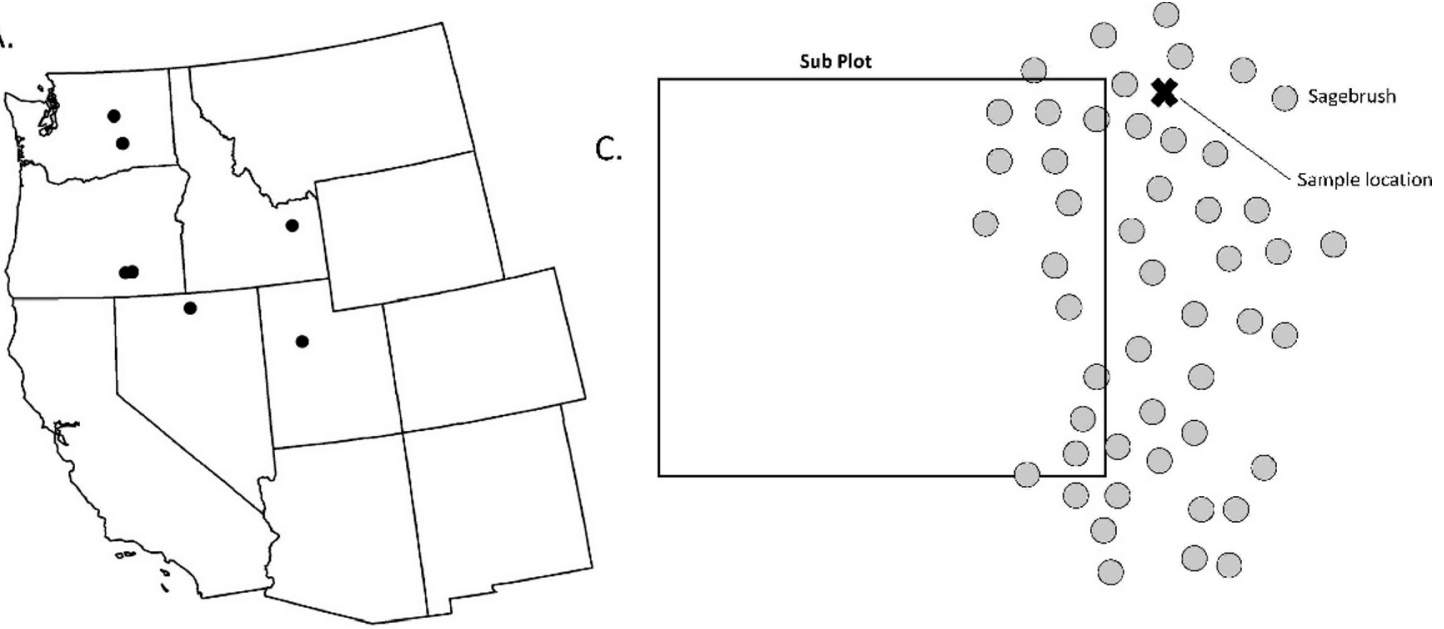

B.
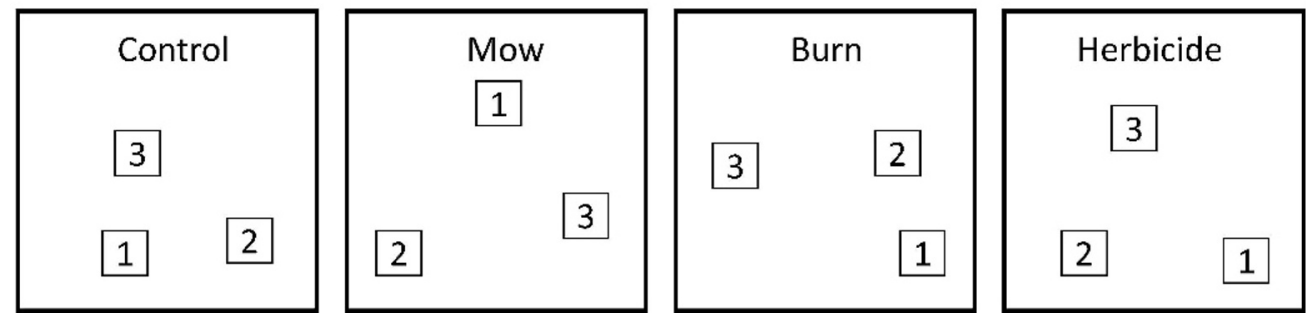

Figure 1. Panel A, Location of the seven sagebrush steppe sites in the intermountain western United States. Panel B, Generalized subplot layout within core plots at each site. Panel C, Sample location at each subplot.

and invasion of exotic annual grasses such as cheatgrass (Bromus tectorum L.), which can convert a site to near monoculture (Miller and Tausch 2001; Chambers et al. 2007).

Vegetation shifts can have large impacts on biogeochemical cycles in established ecosystems including changes in organic carbon (OC) and total nitrogen (N) accumulation (Schimel et al. 1991, 1994). The sagebrush steppe is a fire-adapted ecosystem with fire return intervals ranging from 20-90 yr (Miller and Tausch 2001). Annual grass invasion can reduce aboveground carbon $(\mathrm{C})$ and $\mathrm{N}$ pools, and decrease fire return interval resulting in further $\mathrm{C}$ and $\mathrm{N}$ losses (D'Antonio and Vitousek 1992; Bradley et al. 2006). Similarly, sagebrush steppe conversion to annual grass dominance could reduce belowground C pools due to altered belowground interactions related to litter decomposition, root exudation, and soil biota (Schlesinger 1977; Norton et al. 2004). Changes in these processes alter the input vs. respiration balance, which drives belowground $\mathrm{C}$ and $\mathrm{N}$ accumulation (Norton et al. 2008). Much of the current research and literature related to cheatgrass invasion and $C$ pools has focused on aboveground biomass (Bradley et al. 2006). However, most $\mathrm{C}$ and $\mathrm{N}$ in these arid ecosystems are stored in soils (Hooker et al. 2008). Research on soil OC and invasives often focuses on surface soil processes (Ogle et al. 2004; Wolkovich et al. 2010). There are several papers that describe deeper soil profile changes (Norton et al. 2004; Blank 2008; Hooker et al. 2008); however, these studies were from individual sites (Blank 2008; Hooker et al. 2008) or concentrated on one geographic area (Norton et al. 2004). The current studies show conflicting results for the influence of cheatgrass invasion on soil OC. Studies report increasing soil OC in shallow horizons (Ogle et al. 2004). Others report increases in soil OC through the entire soil profile (Blank 2008; Hooker et al. 2008), and still others report increases in soil OC in near-surface horizons, but decreases in soil OC deeper in the soil profile (Norton et al. 2004). None of the current literature reports data on OC associated with $>2 \mathrm{~mm}$ coarse fragments (rocks). Several researchers have documented the importance of including coarse fragment estimates in C budgets (Fernandez et al. 1993; Ugolini et al. 1996; Corti et al. 1998; Harrison et al. 2003). Given the current interest in $\mathrm{CO}_{2}$ emissions and their interaction with climate, we must attempt to quantify all OC pools when we discuss the effects of invasive species on OC sequestration. This study is an attempt to quantify total belowground OC changes associated with cheatgrass invasion over a broad geographic area. We sampled seven sagebrush steppe sites with variable degrees of cheatgrass invasion within each site. This differs from previous studies which primarily have focused on comparisons between healthy sagebrush systems and cheatgrass monocultures. With these data, we attempt to answer several questions: 1) Does cheatgrass invasion affect belowground storage of $\mathrm{C}$ and $\mathrm{N}$ ? 2) Does cheatgrass invasion affect the partitioning of root and soil pools of $\mathrm{C}$ and $\mathrm{N}$ ? and 3) What are the primary factors associated with belowground organic $\mathrm{C}$ retention in sagebrush steppe ecosystems?

\section{METHODS}

\section{Experimental Area}

This study is part of the Sagebrush Steppe Treatment Evaluation Project (SageSTEP) (www.sagestep.org). The seven sagebrush 
Table 1. Names, USDA soil classification, parent material, location (latitude and longitude), elevation, mean annual precipitation (MAP), mean annual temperature (MAT), and soil depth to bedrock or a restriction for the seven research sites within the SageSTEP network.

\begin{tabular}{|c|c|c|c|c|c|c|c|c|}
\hline Site & Soil classification & Geology & Latitude & Longitude & $\begin{array}{l}\text { Elevation } \\
\quad(\mathrm{m})\end{array}$ & $\begin{array}{l}\text { MAP } \\
(\mathrm{mm})\end{array}$ & $\begin{array}{l}\text { MAT } \\
\left({ }^{\circ} \mathrm{C}\right)\end{array}$ & Depth (cm) \\
\hline Onaqui & $\begin{array}{l}\text { Loamy-skeletal, mixed, active, } \\
\text { mesic Xeric Haplocalcids }\end{array}$ & $\begin{array}{l}\text { Limestone } \\
\text { alluvium }\end{array}$ & 40.19914166 & -112.46043876 & 1660 & 300 & 9 & 70 to $>90$ \\
\hline Owyhee & $\begin{array}{l}\text { Loamy, mixed, superactive, } \\
\text { mesic, shallow Vitrixerandic } \\
\text { Argidurids }\end{array}$ & $\begin{array}{l}\text { Ash and Loess } \\
\text { over Basalt } \\
\text { residuum }\end{array}$ & 41.54761696 & -116.88509809 & 1621 & 307 & 8 & 52 to $>90$ \\
\hline Roberts & $\begin{array}{l}\text { Loamy, mixed, superactive, } \\
\text { frigid Lithic Xeric Haplocalcids }\end{array}$ & Loess over Basalt & 43.76891468 & -112.28263537 & 1483 & 263 & 6 & 9 to $>90$ \\
\hline Grey Butte & $\begin{array}{l}\text { Loamy, mixed, superactive, } \\
\text { frigid, shallow Xeric } \\
\text { Haplodurids }\end{array}$ & Basalt/Tuff & 42.71219641 & -119.43315265 & 1462 & 275 & 8 & 40 to $>90$ \\
\hline Moses Coulee & $\begin{array}{l}\text { Loamy-skeletal, mixed, } \\
\text { superactive, mesic Calcidic } \\
\text { Haploxerolls }\end{array}$ & $\begin{array}{l}\text { Glacial Outwash/ } \\
\text { Loess }\end{array}$ & 47.61747465 & -119.68126830 & 632 & 258 & 9 & 15 to $>90$ \\
\hline Rock Creek & $\begin{array}{l}\text { Loamy, mixed, superactive, } \\
\text { frigid, shallow Xeric } \\
\text { Haplodurids }\end{array}$ & Basalt/Tuff & 42.71718456 & -119.49088703 & 1462 & 275 & 8 & 26 to $>90$ \\
\hline Saddle Mountain & $\begin{array}{l}\text { Coarse-silty, mixed, superactive, } \\
\text { mesic Xeric Haplocambids }\end{array}$ & $\begin{array}{l}\text { Loess over } \\
\text { Lacustrine }\end{array}$ & 46.74985749 & -119.35260281 & 303 & 215 & 11 & 48 to $>90$ \\
\hline
\end{tabular}

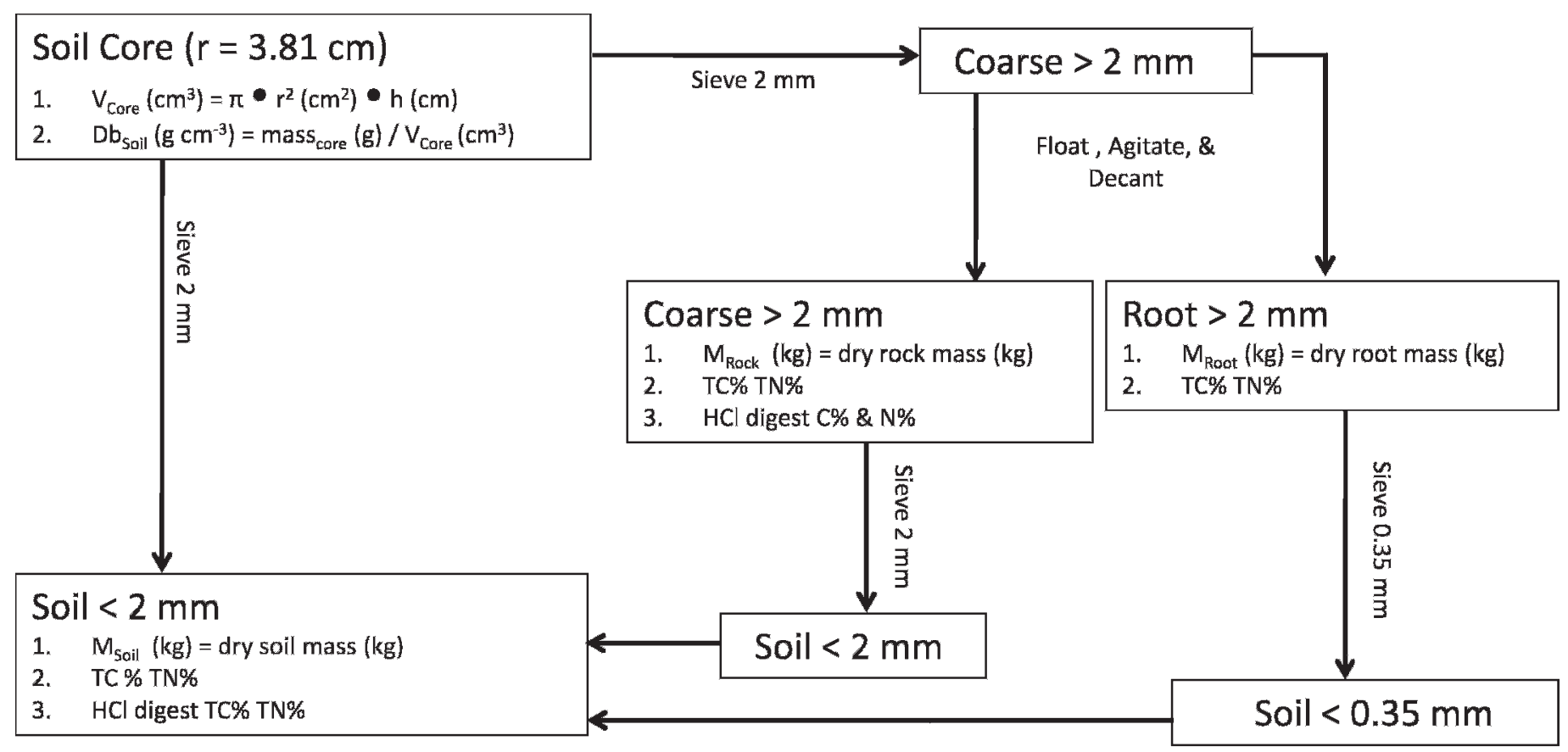

$$
\begin{aligned}
& \text { Roots }>2 \mathrm{~mm}\left(\mathrm{Kg} \mathrm{ha}^{-1}\right)=\left\{\mathrm{M}_{\text {Root }}(\mathrm{kg}) / \mathrm{V}_{\text {core }}\left(\mathrm{cm}^{3}\right)\right\} \cdot \mathrm{d}(\mathrm{cm}) \cdot 100,000,000\left(\mathrm{~cm}^{2}\right) \cdot \mathrm{C} \\
& \text { Coarse }>2 \mathrm{~mm}\left(\mathrm{Kg} \mathrm{ha}^{-1}\right)=\left\{\mathrm{M}_{\text {Coarse }}(\mathrm{kg}) / \mathrm{V}_{\text {core }}\left(\mathrm{cm}^{3}\right)\right\} \cdot \mathrm{d}(\mathrm{cm}) \cdot 100,000,000\left(\mathrm{~cm}^{2}\right) \cdot \mathrm{C} \\
& \text { Soil }<2 \mathrm{~mm}\left(\mathrm{Kg} \mathrm{ha}^{-1}\right)=\left\{\mathrm{M}_{\text {soil }}(\mathrm{kg}) / \mathrm{V}_{\text {core }}\left(\mathrm{cm}^{3}\right)\right\} \cdot \mathrm{d}(\mathrm{cm}) \cdot 100,000,000\left(\mathrm{~cm}^{2}\right) \cdot \mathrm{C} \\
& \text { Where }(\mathrm{C})=\text { nutrient concentration in fraction \% and }(\mathrm{d})=\text { depth of the core increment }
\end{aligned}
$$

Figure 2. Sample processing regime and unit conversion for each core increment extracted. 
Table 2. Results from the generalized linear mixed models comparing belowground organic carbon (OC) and total nitrogen (N).

\begin{tabular}{|c|c|c|c|c|c|c|c|c|c|c|c|c|c|}
\hline \multirow[b]{2}{*}{ Effect } & \multirow{2}{*}{\multicolumn{2}{|c|}{ df }} & \multicolumn{4}{|c|}{$\begin{array}{l}\text { Soil OC } \\
\text { content }\end{array}$} & \multicolumn{2}{|c|}{$\begin{array}{l}\text { Root OC } \\
\text { content }\end{array}$} & \multicolumn{3}{|c|}{$\begin{array}{c}\text { Coarse OC } \\
\text { content }\end{array}$} & \multicolumn{2}{|c|}{$\begin{array}{l}\text { Total belowground } \\
\text { OC content }\end{array}$} \\
\hline & & & $F$ & $\operatorname{Pr}>F$ & $F$ & $\operatorname{Pr}>F$ & $F$ & $\operatorname{Pr}=$ & $F$ & & $>F$ & $F$ & $\operatorname{Pr}>F$ \\
\hline Phase & \multicolumn{2}{|r|}{2} & 4.53 & 0.0114 & 1.43 & 0.2441 & 0.13 & 0.87 & 0.1 & & 3691 & 1.07 & 0.3459 \\
\hline Phase (Site) error a & \multicolumn{2}{|c|}{82} & & & & & & & & & & & \\
\hline Depth & \multicolumn{2}{|r|}{5} & 11.91 & $<0.0001$ & 4.20 & 0.0010 & 3.03 & 0.00 & 9.23 & & 001 & 3.68 & 0.0029 \\
\hline Phase by Depth & \multicolumn{2}{|c|}{10} & 0.74 & 0.6895 & 1.86 & 0.0486 & 0.21 & 0.99 & 0.38 & & 9543 & 1.88 & 0.0463 \\
\hline \multicolumn{14}{|l|}{ Treatment by Phase } \\
\hline \multirow[b]{2}{*}{ Effect } & \multirow[b]{2}{*}{ df } & \multicolumn{2}{|c|}{ Soil N \% } & \multicolumn{2}{|c|}{$\begin{array}{l}\text { Soil N } \\
\text { content }\end{array}$} & \multicolumn{2}{|c|}{$\begin{array}{l}\text { Root N } \\
\text { content }\end{array}$} & \multicolumn{2}{|c|}{$\begin{array}{c}\text { Coarse N } \\
\text { content }\end{array}$} & \multicolumn{2}{|c|}{$\begin{array}{c}\text { Total belowground } \\
\text { N content }\end{array}$} & \multicolumn{2}{|r|}{$\mathrm{C}: \mathrm{N}$} \\
\hline & & $F$ & $\operatorname{Pr}>F$ & $F$ & $\operatorname{Pr}>F$ & $F$ & $P>F$ & $F$ & $\operatorname{Pr}>F$ & $F$ & $\operatorname{Pr}>F$ & $F$ & $\operatorname{Pr}>F$ \\
\hline Phase & 2 & 1.35 & 0.2612 & 0.28 & 0.7531 & 0.19 & 0.8271 & 0.13 & 0.8767 & 0.27 & 0.7677 & 0.35 & 0.7061 \\
\hline Phase (Site) error a & 82 & & & & & & & & & & & & \\
\hline Depth & 5 & 15.97 & $<0.0001$ & 6.32 & $<0.0001$ & 4.6 & 0.0005 & 10.79 & $<0.0001$ & 4.28 & 0.0008 & 1.73 & 0.1269 \\
\hline Phase by Depth & 10 & 0.55 & 0.855 & 1.81 & 0.0570 & 0.22 & 0.9942 & 0.34 & 0.9685 & 1.81 & 0.0576 & 0.49 & 0.8961 \\
\hline $\begin{array}{c}\text { Treatment by Phase } \\
\text { (Site) error b }\end{array}$ & 391 & & & & & & & & & & & & \\
\hline
\end{tabular}

steppe sites for this study are spread across more than $1000 \mathrm{~km}$ from central Washington to west central Utah (Fig. 1A). Although all seven sites are typical sagebrush steppe systems, they encompass a substantial range of conditions in terms of soil types, plant communities, and the typical weather patterns observed (McIver et al. 2010). Soils within the network are typic aridisols, molisols, or entisols; most have sandy loam or silt loam surface textures; and most vary in depth from $9 \mathrm{~cm}$ to $>1 \mathrm{~m}$ (Table 1 ).

\section{Sample Collection and Processing}

Each of the seven sites contained four core treatment plots (50-200 ha) which had a fuels reduction and ecosystem maintenance treatment implemented after sampling (Fig. 1B). For this study treatment is not considered and each core treatment plot is a replicate within site. Subplots $(0.1$ ha) within the core treatment plots were used to quantify vegetation cover and biomass at each location (McIver et al. 2010). All plots had intact sagebrush components ranging from $5 \%$ to $47 \%$ areal cover, and annual grass cover on subplots ranged from $0 \%$ to $50 \%$ areal cover. To assess how increasing cheatgrass cover influenced soil OC and total $\mathrm{N}$, we selected three subplots based on their relative cheatgrass cover. Each of the three subplots selected within a core plot had similar soil physical properties and sagebrush cover, but

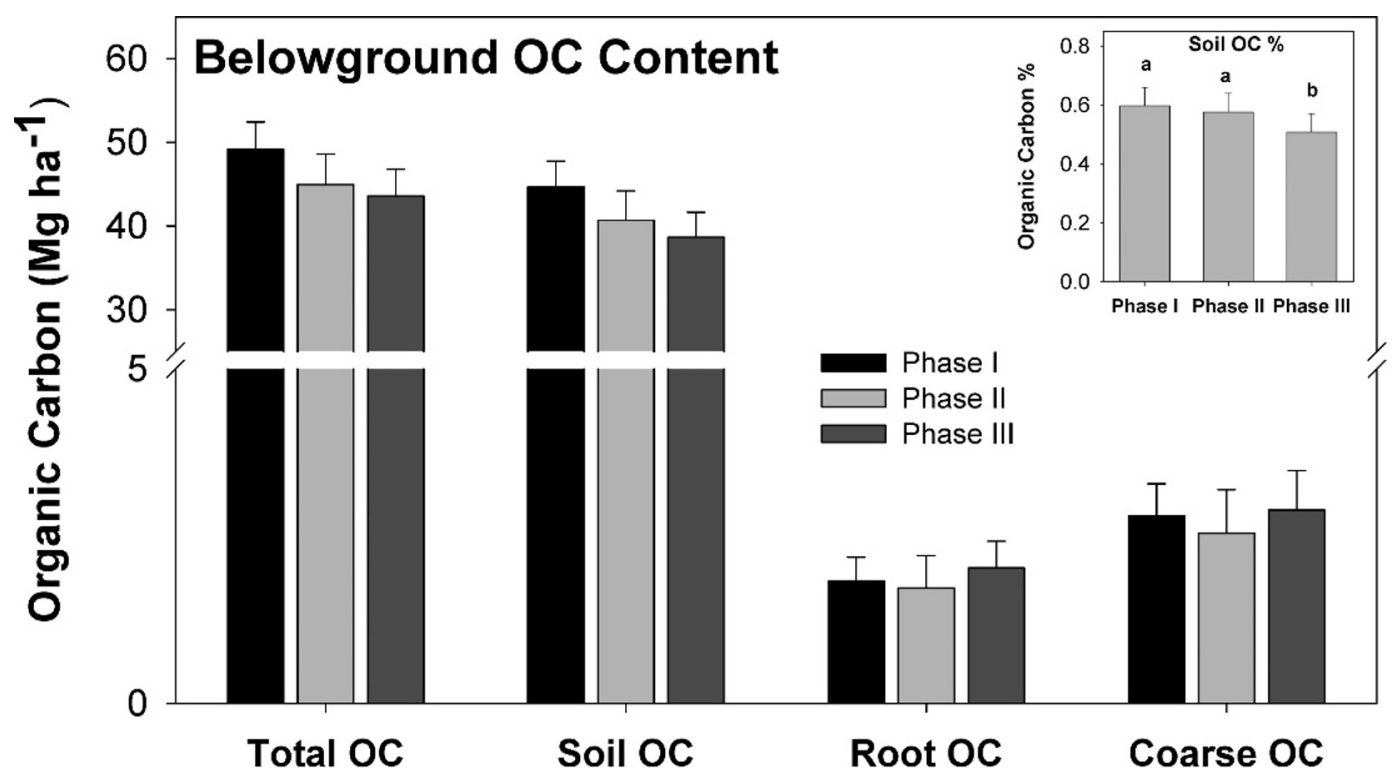

Figure 3. Means and standard errors by phase of cheatgrass invasion for total belowground organic carbon content, soil organic carbon content, root organic carbon content, coarse fragment organic carbon content, and soil organic carbon percent. Lowercase letters represent statistical groups determined by the phase term in the generalized linear mixed model and Tukey's means comparisons $(P<0.05)$. Means with different letters are statistically different. 
represented a different level of cheatgrass invasion. Extent of cheatgrass invasion was determined by dividing cheatgrass cover on each subplot by the total herbaceous understory cover (perennial grass + perennial forb + annual grass + annual forb) on each subplot. Subplots were than ranked as phase I, II, and III by relative annual grass cover within each core plot. By using relative cheatgrass cover rather than total cheatgrass cover we might be able to estimate how much of a site's potential herbaceous component has been converted to annual grass dominance. Total shrub, herbaceous, and cheatgrass cover was variable between sites. Subplots with the lowest cheatgrass relative cover were assigned phase I status and had a mean of $16 \%$ relative cheatgrass cover. Plots with intermediate relative cheatgrass cover were assigned phase II status (mean 25\%). Subplots with the highest cheatgrass relative cover were assigned phase III status (mean 38\%). In order to minimize disturbance to individual subplots, we sampled soils on the northeast corner of each plot (Fig. 1C). At each subplot, a soil core was taken from shrub interspaces using a two-person power auger retrofitted with a diamondtipped core bit (Rau et al. 2009). This device allows workers to core through large rock fragments and coarse roots to bedrock or a similar obstruction. The device also allows workers to estimate the bulk density of each soil increment if accurate depth measurements are taken. This methodology should provide similar estimates of belowground nutrient pools previously thought obtainable only from quantitative soil pits (Hamburg 1984; Harrison et al. 2003; Johnson et al. 2007). Soil cores were $7.62 \mathrm{~cm}$ in diameter and taken in $15-\mathrm{cm}$ increments to a depth of $90 \mathrm{~cm}$ or until an impenetrable obstruction was encountered. Soil cores were placed in plasticlined paper bags, returned to the lab and dried at $50^{\circ} \mathrm{C}$ for $48 \mathrm{~h}$, then weighed. Cores were sieved to $2 \mathrm{~mm}$, and the coarse fragment was submerged and agitated in deionized water to separate roots from coarse mineral fragments by flotation, to break up soil aggregates which did not pass though the sieve, and to remove adhered soil particles from roots and coarse fragments. Roots and water were decanted off coarse fragments, and passed through a $0.35 \mathrm{~mm}$ sieve into a drying tray to separate roots from water. Some $<2 \mathrm{~mm}$ sediment remained with the coarse fragment samples. The separate coarse fragment, root, and water fractions were redried at $50^{\circ} \mathrm{C}$. After drying, $<2 \mathrm{~mm}$ soil particles that had adhered to coarse fragments and roots prior to flotation again was separated from coarse fragments using a $2 \mathrm{~mm}$ sieve. The sediment that was decanted along with roots, but which passed through the $0.035 \mathrm{~mm}$ sieve was removed from the drying tray and added back to the original $<2 \mathrm{~mm}$ fraction along with the second fraction separated from coarse fragments. The mass of all three fractions ( $>2 \mathrm{~mm}$ roots, $>2 \mathrm{~mm}$ coarse fragments, and $<2 \mathrm{~mm}$ soil) was then determined (Fig. 2). Although this method is time consuming, we believe it maximizes separation of fractions and minimizes the cross contamination between fractions. Each fraction was then ground using an Udi cyclone $^{\mathrm{TM}}$ or IKA impact head ${ }^{\mathrm{TM}}$ type mill. Soil and coarse fragment samples were subjected to a test for inorganic carbon using $0.1 \mathrm{M} \mathrm{HCl}$. Samples that tested positive for inorganic C were completely digested with $0.1 \mathrm{M} \mathrm{HCl}$ to remove inorganic $\mathrm{C}$ (Sollins et al. 1999). Five samples $(<2 \mathrm{~mm}$ untreated soil, $<2 \mathrm{~mm} \mathrm{HCl}$-treated soil, $>2 \mathrm{~mm}$ untreated coarse fragments,
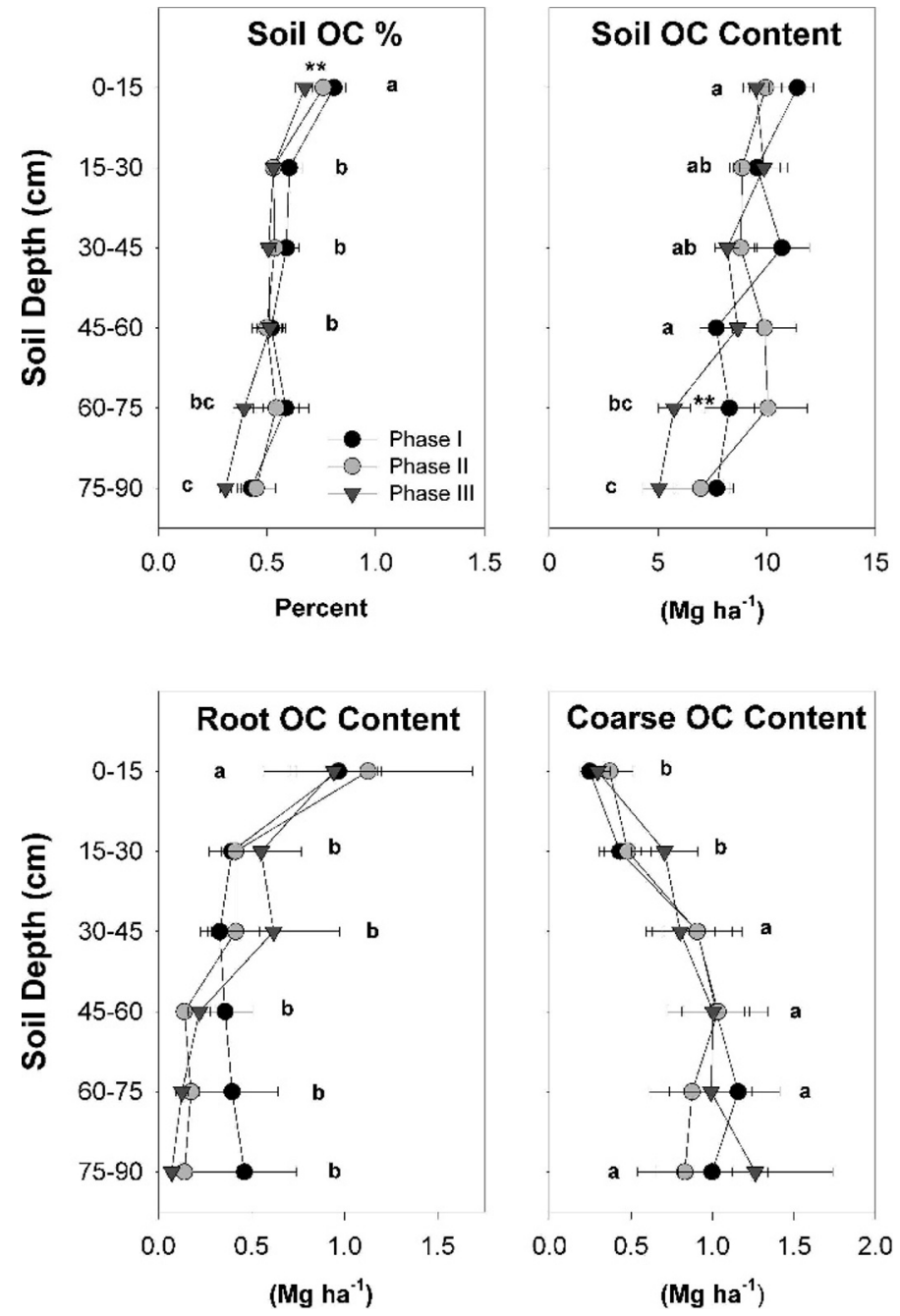

Figure 4. Means and standard errors by phase of cheatgrass invasion and soil depth increment for percent soil organic carbon, soil organic carbon content, root organic carbon content, and coarse fragment organic carbon content. Lowercase letters represent statistical groups for differences determined by the depth term in the generalized linear mixed model and Tukey's means comparisons $(P<0.05)$. Means with different letters are statistically different. Asterisks indicate differences determined by the phase by depth interaction term in the generalized linear mixed model and Tukey's means comparisons $(P<0.05)$.

$>2 \mathrm{~mm} \mathrm{HCl}$-treated coarse fragments, and $>2 \mathrm{~mm}$ organic) for each core sample were analyzed using a LECO Truspec ${ }^{\circledR}$ $\mathrm{CN}$ analyzer. For soil and coarse fragment material, the instrument was calibrated using a certified standard containing $1.30 \% \mathrm{C}$ and $0.130 \% \mathrm{~N}$; for roots, the instrument was calibrated using EDTA (41.02\% C, 9.57\% N). The $\mathrm{HCl}$ digest method can remove a small amount of organic $\mathrm{C}$ and total $\mathrm{N}$ from the samples, which might result in an underestimate of OC percent and total $\mathrm{N}$ percent in our samples (Sollins et al. 1999). Percent OC and total $N$ were multiplied by each sample fraction's mass to obtain the mass of OC and total $\mathrm{N}$ per core sample. Dividing each fraction's OC and total $\mathrm{N}$ mass by the core volume and multiplying by the sample depth gives the mass of OC and total $\mathrm{N}$ per sample per unit area, and the sum of all samples from each core gives total OC and total $\mathrm{N}$ per unit area (Fig. 2). 


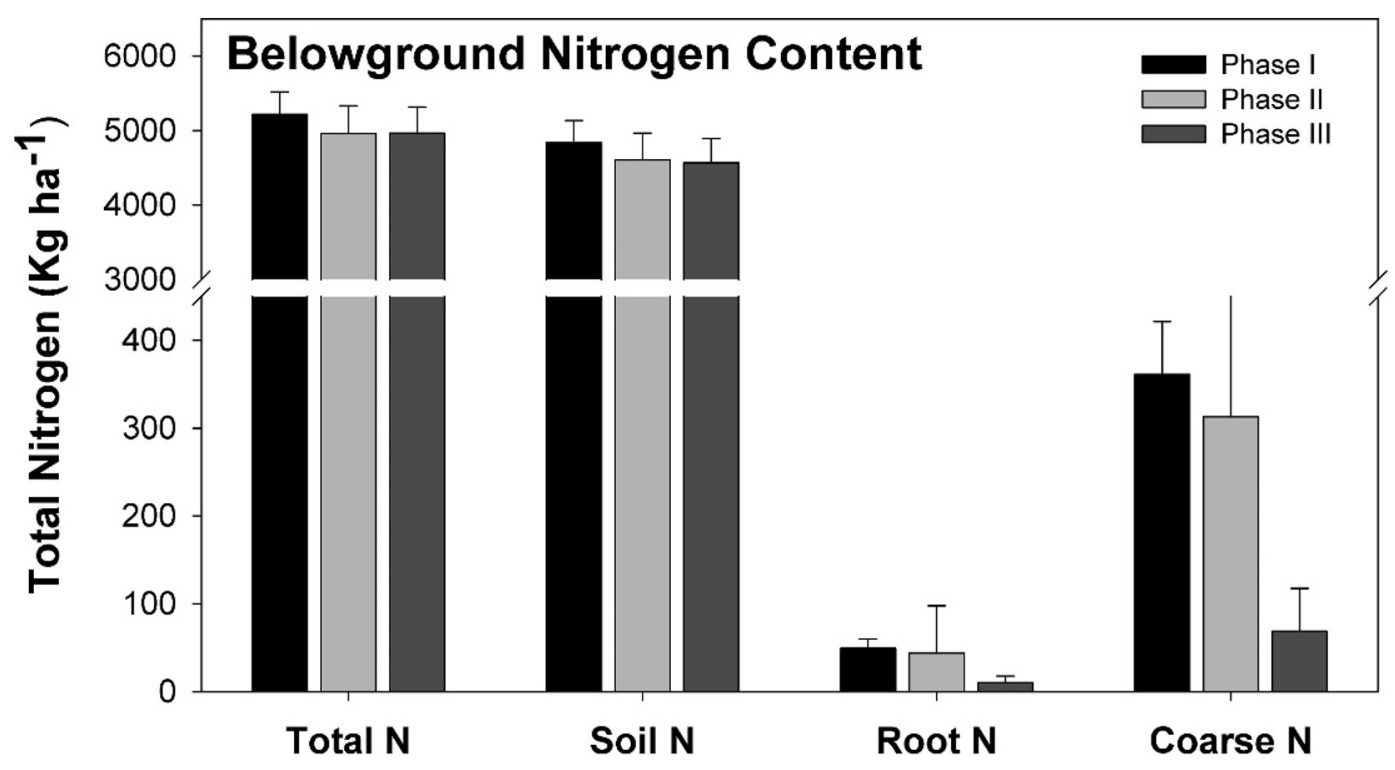

Figure 5. Means and standard errors by phase of cheatgrass invasion for total belowground nitrogen content, soil nitrogen content, root nitrogen content, and coarse fragment nitrogen content.

\section{Statistical Analyses}

Five variables for belowground OC (soil OC percent, soil OC content, root OC content, coarse fraction OC content, and total belowground $\mathrm{OC})$ were analyzed for the influence of annual grass invasion, soil depth, and their interactions. Similarly, six variables (soil $\mathrm{N}$ percent, soil $\mathrm{N}$ content, root $\mathrm{N}$ content, coarse fraction $\mathrm{N}$ content, total belowground $\mathrm{N}$, and $\mathrm{C}: \mathrm{N})$ for total belowground $\mathrm{N}$ were analyzed.

All comparisons were evaluated using SAS $^{\mathrm{TM}}$ generalized linear mixed models (Proc GLIMMIX). Differences in organic $\mathrm{C}$ and total $\mathrm{N}$ were evaluated by treating phase of annual grass invasion as main effect, soil depth was a split plot within annual grass invasion, and site was a considered a random affect $(\alpha=0.05)$. Means comparisons were made using Tukey's test $(\alpha=0.05)$.

Stepwise linear regression (SAS Proc REG) was used to determine the main factors related to total belowground organic carbon (root OC + soil OC + rock OC) accumulation in sagebrush steppe experiencing annual grass invasion. The main factors included in the analyses were sample depth, coarse fragment percent, sand percent, silt percent, clay percent, total belowground $\mathrm{N}$, mean annual precipitation, mean annual temperature, shrub cover, perennial herbaceous cover, and annual grass cover. The regression analyses use an iterative process to find the best models for each number of variables utilized by the model. The criteria used to identify the best-fit model were values for the Delta Akaike Information Criterion (AIC) less than 2.0 (Burnham and Anderson 1992).

\section{RESULTS AND DISCUSSION}

\section{Carbon}

Extent of annual grass invasion had a significant effect on soil OC (Table 2; Fig. 3). Phase I and II plots had significantly higher soil OC percent than phase III plots. This indicates that as cheatgrass invasion progresses, soil OC percent decreases.
This same trend is apparent for soil OC content, and total belowground OC content (Fig. 3).

The mixed model also indicates that depth was a statistically significant factor for all OC variables. Soil OC percent, content, and root OC content all typically decreased with depth, which is typical of most soil profiles (Fig. 4). However, coarse fragment-bound OC content typically increased with soil depth (Fig. 4). This is consistent with the distribution of coarse fragment mass within the soil profile. In our study, we determined that OC content associated with coarse fragments contributed $10 \%$ of total belowground OC estimates. Researchers previously have documented that coarse fragment OC can account for as much as $20 \%$ to $50 \%$ of total belowground OC (Fernandez et al. 1993; Ugolini et al. 1996; Corti et al. 1998; Harrison et al. 2003).

There were significant phase by depth interactions for both soil OC content and total belowground OC content (Table 2). Means comparisons confirm that soil OC content is significantly lower at the $60-75 \mathrm{~cm}$ depth increment in phase III plots compared to phase I and phase II plots (Fig. 4). This is similar to data reported by Norton et al. (2004) who found that cheatgrass monocultures had significantly lower OC in the subsurface compared to uninvaded sagebrush steppe plots. Our data set also is similar to the Norton et al. (2004) data set which shows there is a trend toward decreasing root biomass below $45 \mathrm{~cm}$ with annual grass invasion (Fig. 4). We hypothesize that this is the mechanism responsible for decreasing soil OC with increasing annual grass cover. Annual grasses such as cheatgrass tend to be shallow-rooted species as opposed to perennial grasses and shrubs, which are typically deep-rooted in arid and semiarid environments (Jackson et al. 2000). Fine-root turnover has been proposed as one of the main factors that influence soil OC accumulation (Schlesinger 1977; Richter et al. 1999). Comparing total belowground OC content between phase I plots and phase III plots, we could estimate that the loss of root biomass and soil OC in the subsurface could result in 6-9 $\mathrm{Mg} \cdot \mathrm{ha}^{-1}$ of belowground OC lost by the 
replacement of perennial herbaceous vegetation with annual grass. This represents nearly twice the amount of OC lost from aboveground biomass due to cheatgrass conversion of sagebrush ecosystems (Bradley et al. 2006; Hooker et al. 2008). We further hypothesize that the loss of belowground OC even could be larger if shrubs and their root systems are removed via disturbance or competition and decomposition.

Our data do not support the hypotheses proposed by Ogle et al. (2004) that annual grass invasion increased soil OC content, after using the CENTURY model to verify data collected from the top $20 \mathrm{~cm}$ of soil. However, the Ogle et al. (2004) observations are consistent with observations made by Norton et al. (2004), Blank (2008), and Hooker et al. (2008) who have documented that annual grass invasions can increase near-surface soil OC. However, Norton et al. (2004) also documented the decrease in soil OC at depth that we describe. The decrease of soil $\mathrm{OC}$ at depth easily offset gains near the surface in their study. We therefore suggest that cheatgrass invasion could increase nearsurface OC in certain circumstances, but that these gains often can be offset by OC losses deeper in the soil profile. It is imperative that soils be sampled to the maximum depth feasible or reasonable so that plant-soil interactions can be properly assessed when discussing ecosystem $\mathrm{C}$ and $\mathrm{N}$ budgets.

\section{Nitrogen}

There were no statistically significant changes in soil $\mathrm{N}$ when extent of annual grass invasion was considered alone; however, trends similar to OC are apparent (Table 2; Fig. 5). All soil N variables had statistically significant relationships with soil profile depth, with results identical to those observed for soil OC variables (Fig. 6). There were marginally significant phase by depth interaction terms for soil $\mathrm{N}$ content and total belowground $\mathrm{N}$ (Table 2).

Means comparisons confirm that phase III plots had a slightly lower $\mathrm{N}$ content in the $60-75 \mathrm{~cm}$ soil increment compared to phase I plots (Fig. 6). Several authors have reported increased soil $\mathrm{N}$ content under cheatgrass monocultures (Norton et al. 2004; Blank 2008; Hooker et al. 2008). These data are somewhat surprising, considering that cheatgrass is not an $\mathrm{N}$ fixer. In addition to increased total $\mathrm{N}$, several authors have described increased inorganic $\mathrm{N}$, including $\mathrm{NO}_{3}^{-}$in lower soil horizons (Norton et al. 2004; Blank 2008; Hooker et al. 2008). This is logical if we accept that root biomass and therefore $\mathrm{N}$ uptake has been reduced in lower soil horizons. The loss of root biomass and increasing $\mathrm{NO}_{3}^{-}$concentrations in the subsurface could result in the export of $\mathrm{N}$ from the system during episodic wet periods or in more mesic environments. This might help explain the loss of $\mathrm{N}$ in the subsurface on our sites. $\mathrm{N}$ loss certainly might not be universal and might depend on climate and also atmospheric deposition rates.

Nitrogen content of the coarse fraction typically is not measured, but can account for $10 \%$ of total belowground $\mathrm{N}$ estimated to $90 \mathrm{~cm}$ on our sites (Fig. 5). It appears that this pool could be up to ten times larger than the amount of $\mathrm{N}$ found in root biomass (Fig. 5). The $\mathrm{N}$ bound in coarse material could be of several forms: organic and inorganic $\mathrm{N}$ which has worked its way into pores or cracks within the rock surface, organic and inorganic $\mathrm{N}$ bound into sedimentary deposits, and inorganic $\mathrm{N}$ which has been bound into silicate minerals (Ugolini et al. 1996;
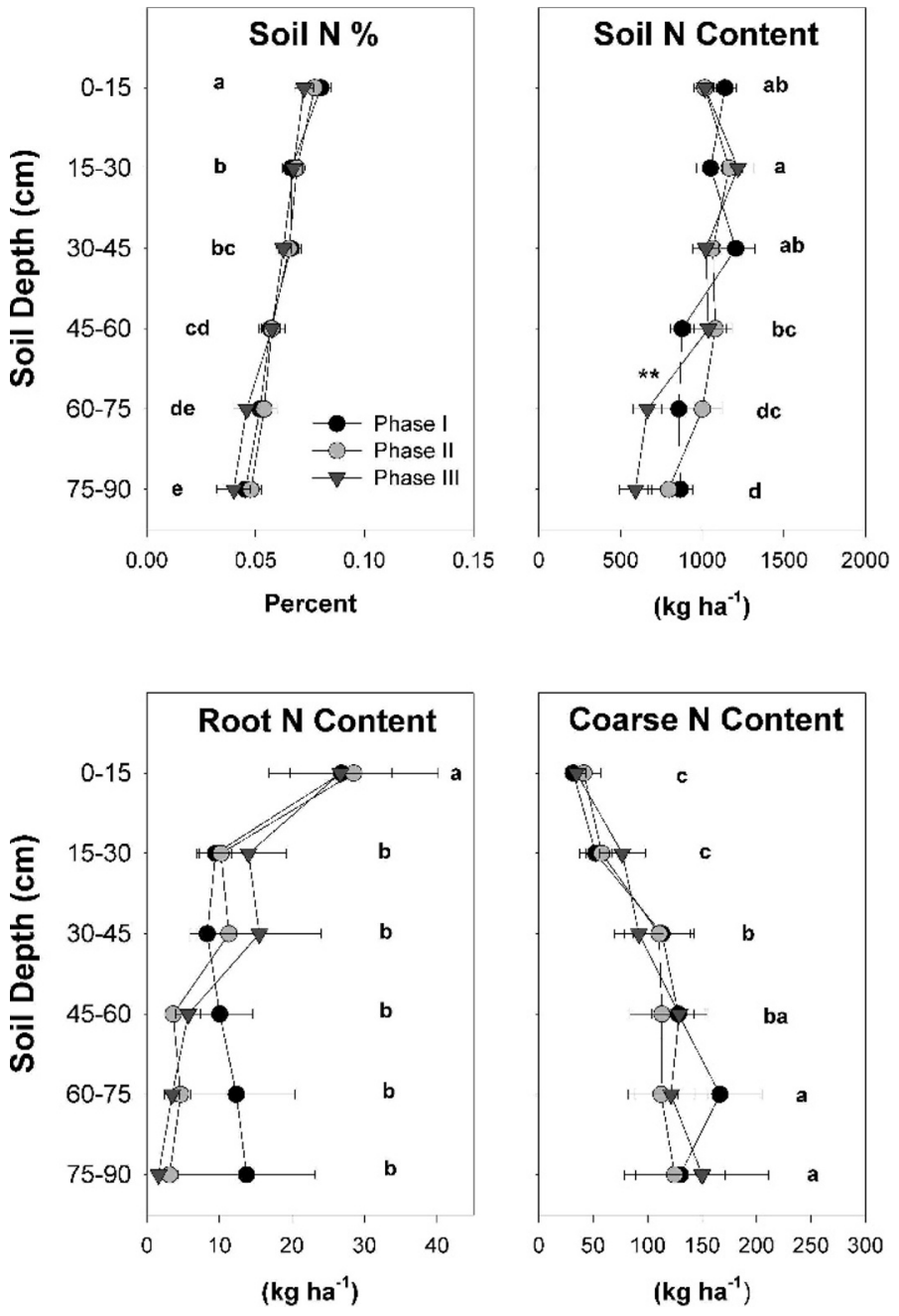

Figure 6. Means and standard errors by phase of cheatgrass invasion and soil depth increment for percent soil nitrogen, soil nitrogen content, root nitrogen content, and coarse fragment nitrogen content. Lowercase letters represent statistical groups for differences determined by the depth term in the generalized linear mixed model and Tukey's means comparisons $(P<0.05)$. Means with different letters are statistically different. Asterisks indicate differences determined by the phase by depth interaction term in the generalized linear mixed model and Tukey's means comparisons $(P<0.05)$.

Holloway and Dahlgren 1999; Bohn et al. 2001; Holloway et al. 2001). Most of our sites are derived from volcanic parent material; therefore, we hypothesize that most of the $\mathrm{N}$ associated with coarse fragments is in the form of organic matter which is adhered to the fragment's surface. Even with careful washing of coarse fragments, this pool remains quite large. We agree with other researchers that not including coarse fragments results in a significant underestimate of belowground N (Fernandez et al. 1993; Ugolini et al. 1996; Corti et al. 1998; Harrison et al. 2003).

\section{Factors Related to Carbon Retention}

The stepwise regression analyses confirm that total belowground $\mathrm{N}$ is the factor most correlated with belowground organic C retention and explains nearly $60 \%$ of the variance (Table 3). Inclusion of variables that define climate explains another $2-3 \%$ of the variance, and further inclusions of 
Table 3. Results from the stepwise linear regression for the best-fit of belowground organic carbon. The best two models are presented for each addition of a new variable in the model.

\begin{tabular}{|c|c|c|c|c|c|c|c|c|c|c|c|c|}
\hline $\begin{array}{l}\text { No. of variables } \\
\text { in model }\end{array}$ & $\operatorname{Var} 1^{1}$ & Var 2 & Var 3 & Var 4 & Var 5 & Var 6 & Var 7 & Var 8 & Var 9 & $\operatorname{Var} 10$ & Var 11 & $r^{2}$ \\
\hline 1 & TN & & & & & & & & & & & 0.587 \\
\hline 1 & MAT & & & & & & & & & & & 0.099 \\
\hline 2 & TN & MAT & & & & & & & & & & 0.609 \\
\hline 2 & TN & MAP & & & & & & & & & & 0.603 \\
\hline 3 & Clay & TN & MAT & & & & & & & & & 0.614 \\
\hline 3 & TN & MAT & Brome & & & & & & & & & 0.613 \\
\hline 4 & Clay & TN & MAT & Shrub & & & & & & & & 0.617 \\
\hline 4 & TN & MAT & Shrub & Herb & & & & & & & & 0.617 \\
\hline 5 & Clay & TN & MAT & Shrub & Herb & & & & & & & 0.621 \\
\hline 5 & Depth & Clay & TN & MAT & Shrub & & & & & & & 0.621 \\
\hline 6 & Sand & Silt & TN & MAT & Shrub & Herb & & & & & & 0.624 \\
\hline 6 & Depth & Clay & TN & MAT & Shrub & Herb & & & & & & 0.624 \\
\hline 7 & Depth & Sand & Silt & TN & MAT & Shrub & Herb & & & & & 0.627 \\
\hline 7 & Coarse & Sand & Silt & TN & MAT & Shrub & Herb & & & & & 0.626 \\
\hline 8 & Depth & Coarse & Sand & Silt & TN & MAT & Shrub & Herb & & & & 0.628 \\
\hline 8 & Depth & Sand & Silt & TN & MAP & MAT & Shrub & Herb & & & & 0.628 \\
\hline 9 & Depth & Coarse & Sand & Silt & TN & MAP & MAT & Shrub & Herb & & & 0.629 \\
\hline 9 & Depth & Coarse & Sand & Silt & Clay & TN & MAT & Shrub & Herb & & & 0.629 \\
\hline 10 & Depth & Coarse & Sand & Silt & TN & MAP & MAT & Shrub & Herb & Brome & & 0.630 \\
\hline 10 & Depth & Coarse & Sand & Silt & Clay & TN & MAP & MAT & Shrub & Herb & & 0.629 \\
\hline 11 & Depth & Coarse & Sand & Silt & Clay & TN & MAP & MAT & Shrub & Herb & Brome & 0.630 \\
\hline
\end{tabular}

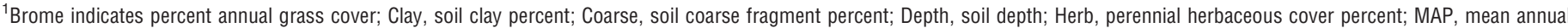
precipitation; MAT, mean annual temperature; Sand, soil sand percent; Shrub, shrub cover percent; Silt, soil silt percent; TN, total nitrogen; Var, variable.

variables that define soil texture and vegetation cover, including annual grass, explain another $1 \%$ of the variance (Table 3). The models suggest that total belowground organic $\mathrm{C}$ consistently and positively is correlated with total belowground $\mathrm{N}$, mean annual precipitation, shrub cover, and perennial herbaceous cover. There are consistent negative correlations with increasing soil depth, coarse fragment content, sand percent, silt percent, mean annual temperature, and annual grass cover. This type of analysis is not meant as a predictive tool, but allows for the confirmation of hypotheses and identification of relationships. Many of these relationships are not surprising. Soil $\mathrm{N}$ is the dominant factor controlling soil OC accumulation and retention (Lal 2008). Vegetation fixes atmospheric $\mathrm{CO}_{2}$ and creates plant parts with $\mathrm{C}: \mathrm{N}$ of $30: 1$ or greater. This biomass is subject to microbial decomposition and eventually can become soil OC with C:N close to 12:1. Microbial metabolism influences the C: $\mathrm{N}$ of soil OC, but the ratio tends not to range far from 12:1. Therefore, soil OC might not accumulate readily without a concurrent increase in soil N (Lal 2008). There was little evidence in our study that annual grass invasion influenced the C:N. Similarly it is commonly accepted that soil OC decreases with soil depth and that coarse-grained soils typically store less OC than finetextured soils. Recent research has emphasized the importance of soil OC stabilization by formation of organo-mineral associations in fine textured soils (Torn et al. 1997; Lutzow et al. 2008). This data set reiterates the influence that abiotic variables have on $\mathrm{OC}$ retention, especially $\mathrm{N}$, but also highlights the interaction that shrubs, perennial herbaceous vegetation, and exotic grass invasion can have on soil OC.

\section{IMPLICATIONS}

Our research suggests that the exotic annual grass Bromus tectorum can reduce total belowground OC in sagebrush steppe ecosystems. Replacement of deep-rooted perennial herbaceous vegetation by shallow-rooted annual grass could be the mechanism by which the reduction in belowground OC occurs. We anticipate that further losses in belowground OC would occur if deep-rooted native shrubs were removed by competition or disturbance such as fire. Conversion of sagebrush steppe ecosystems to annual grass communities results in a decrease in the fire return interval, which could exacerbate the loss of $\mathrm{C}$ and N from these ecosystems (D'Antonio and Vitousek 1992). Given the importance of $\mathrm{N}$ to $\mathrm{OC}$ retention, this could result in long-term site degradation.

We determined that roughly $10 \%$ of belowground OC and N were associated with regolith coarse fragments, and recommend that researchers attempt to quantify these pools in biogeochemical studies. Furthermore we stress the importance of characterizing soil nutrient pools to bedrock, a restriction, or as deep as feasible so that redistribution of nutrients can be properly assessed with vegetation shifts.

\section{ACKNOWLEDGMENTS}

We would like to thank Tye Morgan for assistance in sample processing, and David Pyke, Paul Doescher, Scott Schaff, Jeff Burnham, and all of the field crews for their assistance in gathering vegetation data on the SageSTEP plots. Research was funded by the Joint Fire Sciences Program. This paper is Contribution Number 51 of the Sagebrush Steppe Treatment Evaluation Project (SageSTEP). 


\section{LITERATURE CITED}

BLank, R. R. 2008. Biogeochemistry of plant invasion: a case study with downey brome (Bromus tectorum). Invasive Plant Science and Management 1:266-238.

Bohn, H. L., B. L. McNeal, and G. A. O'Conner. 2001. Soil Chemistry. New York, NY, USA: John Wiley and Sons. $307 \mathrm{p}$.

Bradley, B. A., R. A. Houghton, J. F. Mustard, and S. P. Hamburg. 2006. Invasive grass reduces aboveground carbon stocks in shrublands of the Western US. Global Change Biology 12:1815-1822.

Burnham, K. P., and D. R. Anderson. 1992. Data-based selection of an appropriate biological model: the key to modern data analysis. In: D. R. McCullough and R. H. Barrett [EDS.]. Wildlife 2001: populations. New York, NY, USA: Elsevier Applied Science. p. 16-30.

Chambers, J., B. A. Roundy, R. R. Blank, S. E. Meyer, and A. Whitaker. 2007. What makes Great Basin sagebrush ecosystems invasible by Bromus tectorum? Ecological Monographs 77:117-145.

Corti, G., F. C. Ugolini, and A. Agnelli. 1998. Classing the soil skeleton (greater than two millimeters): proposed approach and procedure. Soil Science Society of America Journal 62:1620-1629.

D'Antonio, C., And P. M. Vitousek. 1992. Biological invasions by exotic grasses, the grass/fire cycle, and global change. Annual Review of Ecology and Systematics 23:63-87.

Fernandez, I. J., L. E. Rustad, and G. B. Lawrence. 1993. Estimating total soil mass, nutrient content, and trace metals in soils under a low elevation spruce-fir forest. Canadian Journal of Soil Science 73:317-328.

HambuRG, S. P. 1984. Effects of forest growth on soil nitrogen and organic matter pools following release from subsistence agriculture. In: E. L. Stone [ED.]. Forest Soils and Treatment Impacts. Knoxville, TN, USA: University of Tennessee. p. 145-158.

Harrison, R. B., A. B. Adams, C. Licata, B. Flaming, G. L. Wagoner, P. Carpenter, and E. D. VANCE. 2003. Quantifying deep-soil and coarse-soil fractions: avoiding sample bias. Soil Science Society of America Journal 67:1602-1606.

Holloway, J. M., and R. A. Dahlgren. 1999. Geologic nitrogen in terrestrial biogeochemical cycling. Geology 27:567-570.

Holloway, J. M., R. A. Dahlgren, and W. H. Casey. 2001. Nitrogen release from rock and soil under simulated field conditions. Chemical Geology 174:403-414.

Hooker, T. D., J. M. Stark, U. Norton, J. A. Leffler, M. Peek, and R. Ryel. 2008. Distribution of ecosystem $\mathrm{C}$ and $\mathrm{N}$ within contrasting vegetation types in a semiarid rangeland, in the Great Basin, USA. Biogeochemistry 90:291-308.

Jackson, R. B., H. J. Schenk, E. G. Jobbágy, J. Canadell, G. D. Colello, R. E. Dickinson, C. B. Field, P. Friedlingstein, M. Heimann, K. Hibbard, D. W. Kicklighter, A. Kleidon, R. P. Neilson, W. J. Parton, O. E. Sala, and M. T. Sykes. 2000. Belowground consequences of vegetation change and their treatment in models. Ecological Applications 10:470-483.

Johnson, D. W., J. F. Murphy, R. F. Walker, D. W. Glass, and W. W. Miller. 2007. Wildfire effects on forest carbon and nutrient budgets. Ecological Engineering 31:183-192.

LAL, R. 2008. Promise and limitations of soils to minimize climate change. Journal of Soil and Water Conseration 63:113-118.

Lutzow, M., I. Kogel-Knabner, B. Ludwig, E. Matzner, H. Flessa, K. Ekschmitt, G. Guggenberger, B. Marschner, and K. Kalbitz. 2008. Stabilization mechanisms of organic matter in four temperate soils: development and application of a conceptual model. Journal of Plant Nutrition and Soil Science 171:111-124.
Mclver, J. D., M. Brunson, S. C. Bunting, And others. 2010. The Sagebrush Steppe Treatment Evaluation Project (SageSTEP): a test of state-and-transition theory. General Technical Report RMRS-GTR-237. Fort Collins, CO, USA: U.S. Department of Agriculture, Forest Service, Rocky Mountain Research Station. $16 \mathrm{p}$.

MilleR, R. F., and R. J. Tausch. 2001. The role of fire in juniper and pinyon woodlands: a descriptive analysis. In: K. E. M. Gallet and T. P. Wilson [EDs.]. Proceedings of the Invasive Species Workshop: The Role of Fire in the Control and Spread of Invasive Species. Tallahassee, FL, USA: Tall Timbers Research Station Miscellaneous Publications No. 11. p. 15-30.

Norton, J. B., T. A. Monaco, J. M. Norton, D. A. Johnson, and T. A. Jones. 2004. Soil morphology and organic matter dynamics under cheatgrass and sagebrushsteppe plant communities. Journal of Arid Environments 57:445-466.

Norton, U., A. R. Mosier, J. A. Morgan, J. D. Derner, L. J. Ingram, and P. D. Stahl. 2008. Moisture pulses, trace gas emissions and soil $C$ and $N$ in cheatgrass and native grass-dominated sagebrush-steppe in Wyoming, USA. Soil Biology \& Biochemistry 40:1421-1431.

Noss, R. F., E. T. Laroe III, and J. M. Scott. 1995. Endangered ecosystems of the United States: a preliminary assessment of loss and degradation. Washington, DC, USA: National Biological Service Biological Report 28, National Biological Service.

Ogle, S. M., D. OJima, and W. Reiners. 2004. Modeling the impact of exotic annual brome grasses on soil organic carbon storage in a northern mixed-grass prairie. Biological Invasions 6:365-377.

Rau, B. M., D. W. Johnson, J. C. Chambers, R. R. Blank, and A. Luccesi. 2009. Estimating root biomass and distribution after fire in a Great Basin woodland using cores and pits. Western North American Naturalist 64:459-463.

Richter, D. D., D. Markewitz, S. E. Trumbore, and C. G. Wells. 1999. Rapid accumulation and turnover of soil carbon in a re-establishing forest. Nature 400:56-58.

Schimel, D. S., B. H. Braswell, E. A. Holland, R. McKeown, D. S. Ojima, T. H. Painter, W. J. Parton, and A. R. Townsend. 1994. Climatic, edaphic, and biotic controls over storage and turnover of carbon in soils. Global Biogeochemical Cycles 8:279-293.

Schimel, D. S., T. G. F. Kittel, and W. J. Parton. 1991. Terrestrial biogeochemical cycles: global interactions with the atmosphere and hydrology. Tellus 43AB:188-203.

SChlesinger, W. H. 1977. Carbon balance in terrestrial detritus. Annual Review of Ecology and Systematics 8:51-58.

Sollins, P., C. Glassman, P. A. Eldor, C. Swanston, K. Lajtha, J. W. Hell, and E. T. Elıוot. 1999. Soil carbon and nitrogen pools and fractions. In: G. P. Robertson, D. C. Coleman, C. S. Bledsoe, and P. Sollins [EDS.]. Standard soil methods for long-term ecological research. Oxford, NY, USA: Oxford University Press. p. 89-105.

Torn, M. S., S. E. Trumbore, O. A. Chadwick, P. M. Vitousek, and D. M. Hendricks. 1997. Mineral control of soil organic carbon storage and turnover. Nature 389:170-173.

Ugolini, F. C., G. Corti, A. Agnelli, and F. Piccardi. 1996. Mineralogical, physical, and chemical properties of rock fragments in soil. Soil Science 161: 521-542.

Wolkovich, E. M., D. A. Lipson, R. A. Virginia, K. L. Cottingham, and D. T. Bolger. 2010. Grass invasion causes rapid increase in ecosystem carbon and nitrogen storage in a semiarid shrubland. Global Change Biology 16:1351-1365. 